\title{
Levels and Influencing Factors of Heavy Metals in Human Hairs from Five Provinces in China
}

\author{
Renjie QIN ${ }^{\mathrm{a}}$, Meiqing JIA ${ }^{\mathrm{a}}$, Wei LUO ${ }^{\mathrm{b}}$ and Guanghong WU ${ }^{\mathrm{a}, 1}$ \\ ${ }^{a}$ Tianjin Key Laboratory of Water Resources and Environment, Tianjin Normal \\ University, Tianjin 300387, China \\ ${ }^{\mathrm{b}}$ Laboratory of Solid Waste Treatment and Recycling, Research Center for \\ Eco-Environmental Science, Chinese Academy of Sciences, Beijing 100085, China
}

\begin{abstract}
Heavy metal concentrations were measured in 150 human hairs samples collected from five provinces in China to investigate heavy metal exposure levels and influencing factors. The gender, age, diet and lifestyle habits of the volunteers were investigated through questionnaires to analyze their effects on hair element concentrations. Metal concentrations in hair were $1.62 \mu \mathrm{g} / \mathrm{g}(\mathrm{Mn}), 0.99 \mu \mathrm{g} / \mathrm{g}(\mathrm{Co})$, $0.22 \mu \mathrm{g} / \mathrm{g}(\mathrm{Cd})$ and $8.49 \mu \mathrm{g} / \mathrm{g}(\mathrm{Pb})$, which were low compared with those reported in mine contaminated areas. Cd concentration was higher in females than males, $\mathrm{Pb}$ concentration was lower in the elder group and the younger group. No difference of $\mathrm{Cd}$ and $\mathrm{Co}$ concentrations among rice consumers and/or wheat consumers was found. $\mathrm{Pb}$ concentration in rice consumers were higher than those in rice and/or wheat consumers. Fish consumption were a factor affecting hair $\mathrm{Cd}$ and $\mathrm{Pb}$ levels, while smoking was not one main pathway of hair $\mathrm{Cd}$ and $\mathrm{Pb}$ exposure.
\end{abstract}

Keywords. Human hair, heavy metals, gender differences, age, dietary intake

\section{Introduction}

Heavy metal pollution continues to be a global public health issue, human biomonitoring is a method that can be used to assess the impact of heavy metals present in the environment on living organisms [1]. Body fluids (urine and blood), finger and toe nails, hair are commonly used to assess heavy metals exposure [2,3]. Since slowness in growing and incorporating heavy metals, hair could minimize exposure fluctuations and be considered as tracers of longer exposure periods than urine and blood [2]. Hair sampling was safe and not invasive, easier for storage and carriage, which was considered as an interesting biomonitoring material to evaluate heavy metals exposure in human [3].

Previous studies of heavy metals in human hair were mostly focused on health risks corresponding to a particular area of an open-cast lead-zinc mine, mine contaminated area, industrial regions, and urban environment [3-6]. Dietary intake of fishes was considered as a main path for human exposure to $\mathrm{Hg}$ [7]. $\mathrm{Cd}$ and $\mathrm{Pb}$ were

1 Guanghong $\mathrm{Wu}$, Corresponding author, Tianjin Key Laboratory of Water Resources and Environment, Tianjin Normal University, Tianjin 300387, China; E-mail: wuguanghong@hotmail.com. 
also main heavy metal contaminants related with human health [8]. There was a lack of detailed study of the influences of these factors on heavy metal contents in hair. Human health risks related to $\mathrm{Cd}$ and $\mathrm{Pb}$ contamination caused by fish and rice dietary intake have not been widely analyzed. To address this understanding gap, gender, age, and lifestyles (smoking), dietary habit (e.g., aquatic products, rice and/or wheat consumptions) were considered as factors responsible for $\mathrm{Cd}, \mathrm{Pb}, \mathrm{Co}$, and $\mathrm{Mn}$ levels in hair. The aims of the present study were to quantify the levels of $\mathrm{Cd}, \mathrm{Pb}, \mathrm{Co}$ and $\mathrm{Mn}$ in human hair from five provinces in China and identify the interactive effects of the factors (e.g., region, gender, age, lifestyles, dietary habit) on hair toxic metal levels.

\section{Materials and Methods}

\subsection{Sample Collection}

A total of $150(30 \times 5)$ human hair samples were collected from the local barber shops in Hainan (HN), Yunnan (YN), Sichuan (SC), Shaanxi (SX) and Inner Mongolia (NM), China. About $2 \mathrm{~g}$ hair sample was taken from volunteers with clean scissors, then put in clean polyethylene bags. Questionnaires were also conducted during the hair sample collection process to obtain the volunteer's personal information (gender, age and place of residence, etc.), lifestyle (smoking or nonsmoking), and food habit (staple and non-staple foods, aquatic products, etc.). The present study was conducted on residents who had lived in the area for more than 3 years and the ages were between 15 and 75 . The statistical result of the volunteer information was generalized in table 1 .

Table 1. Statistical result of volunteer information

\begin{tabular}{|c|c|c|c|}
\hline Index & \multicolumn{3}{|c|}{ Number of people and proportion } \\
\hline Gender & Male $77(45.8 \%)$ & & nale $91(54.2 \%)$ \\
\hline Age & $\leq 86(51.2 \%)$ & & $2(48.8 \%)$ \\
\hline Smoking habit & Yes $67(39.9 \%)$ & & $101(60.1 \%)$ \\
\hline Aquatic product frequency & Frequently: $50(29.8 \%)$ & & requently: $118(70.2 \%)$ \\
\hline Food habit(staple food) & Rice: $98(58.3 \%)$ & Wheat: $49(29.2 \%)$ & $\begin{array}{l}\text { Both rice and wheat: } \\
21(12.5 \%)\end{array}$ \\
\hline
\end{tabular}

\subsection{Sample Processing and Testing}

Human hair samples were washed with acetone, super pure water, and then acetone to confirm there was no external contaminants. After that, hair was dried in a stove for 2 hours at $60{ }^{\circ} \mathrm{C}$. Hairs were dissected into small pieces $(3 \mathrm{~mm})$ with stainless steel scissor, weighed in gram $( \pm 0.001 \mathrm{~g})$ and placed into polytetrafluoroethylene crucibles. Human hair samples were digested in an electric hot plate with $2.0 \mathrm{ml}$ of concentrated super pure $\mathrm{HNO}_{3}$ and $1.0 \mathrm{ml}$ super pure hydrogen peroxide for $40 \mathrm{~min}$ at $120{ }^{\circ} \mathrm{C}$. The digestion liquid was diluted into $50.00 \mathrm{ml}$ with super pure water. $\mathrm{Cd}, \mathrm{Pb}, \mathrm{Co}$ and $\mathrm{Mn}$ concentrations in human hair were measured with an inductively coupled plasma emission spectrometer (ICP-OES, PE Optima 8300).

\subsection{Statistics and Analysis}

Statistical analysis was conducted using the SPSS 19 software package. The Kolmogorov-Smirnov test was used to verify the distribution of concentrations of Cd, 
$\mathrm{Pb}$, $\mathrm{Co}$ and $\mathrm{Mn}$, indicating not normally distributed $(p<0.05)$; consequently, nonparametric statistics were used in the subsequent statistical analyses. Spearman's correlation analysis was applied to determine the difference between heavy metal combinations. Kruskal-Wallis One-way analysis of variance was used to investigate the differences of heavy metal contents among province. Independent samples t-Test was applied to find the differences between two age groups at a significance level of $p<$ 0.05 . The Mann-Whitney U-Test was applied to find the differences in $\mathrm{Cd}, \mathrm{Pb}, \mathrm{Co}$ and Mn concentrations in food habit and life style.

\subsection{Quality Assurance and Quality Control}

Certified reference material GBW07601a (GSH-1) of hair sample was used for analytical quality control. This experiment's results for concentrations for the three replicates were presented in table 2 . The recoveries of $\mathrm{Cd}, \mathrm{Pb}, \mathrm{Co}$ and $\mathrm{Mn}$ ranged from $69.1 \%$ to $105.5 \%$, indicating that the proposed method was precise and accurate. Standard solution $(0.005 \mathrm{mg} / \mathrm{L})$ was measured after every 10 samples to evaluate the instrument's stability, $10 \%$ of hair samples were randomly selected for double parallel determination. The relative standard deviations for all analytical elements were $<10 \%$.

Table 2. Recovery of human hair certified reference materials [GBW07601a (GSH-1)].

\begin{tabular}{llll}
\hline & Certified value $(\mu \mathrm{g} / \mathrm{g})$ & Observed value $(\mu \mathrm{g} / \mathrm{g})$ & Recovery $(\%)$ \\
\hline $\mathrm{Cd}$ & $1.1 \pm 0.3$ & $1.16 \pm 0.07$ & 105.5 \\
$\mathrm{~Pb}$ & $88 \pm 11$ & $76 \pm 2.284$ & 86.4 \\
$\mathrm{Co}$ & $0.71 \pm 0.12$ & $0.67 \pm 0.06$ & 94.4 \\
$\mathrm{Mn}$ & $63 \pm 8$ & $43.52 \pm 2.82$ & 69.1 \\
\hline
\end{tabular}

\section{Results and Discussion}

\subsection{Heavy Metal Contents in Hair}

Descriptive statistics of $\mathrm{Cd}, \mathrm{Pb}, \mathrm{Co}$ and $\mathrm{Mn}$ contents in human hair collected from five provinces in China were shown in table $3 . \mathrm{Cd}$ and $\mathrm{Pb}$ contents were lower than those around mine contaminated area $(2.466 \mu \mathrm{g} / \mathrm{g}, 20.92 \mu \mathrm{g} / \mathrm{g})$ and around an open-cast lead-zinc mine $(0.75 \mu \mathrm{g} / \mathrm{g}, 6.87 \mu \mathrm{g} / \mathrm{g})$ in China [5,6], but were higher than those measured in urban environment $(0.005-0.223 \mu \mathrm{g} / \mathrm{g}, 0.111-2.966 \mu \mathrm{g} / \mathrm{g}$ for schoolchildren; $0.004-0.153 \mu \mathrm{g} / \mathrm{g}$ and $0.075-1.642 \mu \mathrm{g} / \mathrm{g}$ for adolescents) [4]. The result showed that $\mathrm{Cd}$ and $\mathrm{Pb}$ contents in the present study were lower than those resided and lived in mine contaminated area.

Normality test was confirmed with the Kolmogorov-Smirnov. The results showed that heavy metal contents did not distribute normally $(p<0.05)$ (table 3$)$. Consequently, statistical analyses were conducted with non-parametric techniques. The Kaiser-Meyer-Olkin test $(\mathrm{KMO}=0.62>0.6)$ and the Bartlett's test of sphericity $(p=0.001<0.05)$ were used to analyze the metal concentrations, showing the data were factorable. Principal component analysis (PCA) was conducted to group metal contents. Two significant components were determined by extracting the eigenvalues and eigenvectors (figure 1). Component 1 obtained $39.4 \%$ of the total variance and the weight $1.577(>0.70)$ for $\mathrm{Cd}, \mathrm{Pb}$ and $\mathrm{Mn}$, which were mainly derived from similar source. Component 2 obtained $24.9 \%$ of the total variance and the weight 0.996 for Co. 
The Spearman's rank correlation coefficient was applied to assess the relation among $\mathrm{Cd}, \mathrm{Pb}, \mathrm{Co}$ and $\mathrm{Mn}$ concentrations in hair. $\mathrm{Cd}$ was significantly associated with $\mathrm{Pb}$ $(p<0.01, r=0.63, n=150)$. The results indicated that the general populations have common exposure sources (dairy diet, etc.) to $\mathrm{Cd}$ and $\mathrm{Pb}$. Significant positive relationship for $\mathrm{Cd}-\mathrm{Pb}$ in blood and moderate correlation in urine was obtained in a previous study [9].

Table 3. Normality test of $\mathrm{Co}, \mathrm{Cd}$ and $\mathrm{Pb}$ concentrations $(\mu \mathrm{g} / \mathrm{g})$ in human hair $(\mathrm{n}=150)$

\begin{tabular}{lllllll}
\hline & Mean & RSD & Skewness & Kurtosis & \multicolumn{2}{l}{ Kolmogorov-Smirnov test } \\
\cline { 5 - 6 } & & & & & Statistics D & $\mathrm{p}$ \\
\hline $\mathrm{Cd}$ & 0.22 & 0.24 & 5.50 & 44.18 & 0.238 & $0.000^{* *}$ \\
$\mathrm{~Pb}$ & 8.57 & 9.23 & 4.74 & 31.70 & 0.256 & $0.000^{* *}$ \\
$\mathrm{Co}$ & 0.97 & 0.97 & 3.68 & 17.39 & 0.326 & $0.000^{* *}$ \\
$\mathrm{Mn}$ & 1.64 & 0.96 & 0.98 & 0.74 & 0.256 & $0.000^{* *}$ \\
\hline
\end{tabular}

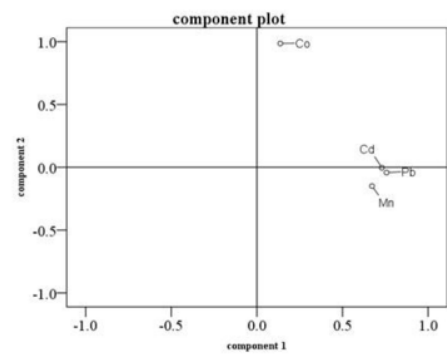

Figure 1. Factor loading scatter of heavy metal concentrations in human hair.

The non-parametric Kruskal-Wallis test was used to investigate the distinctions in hair $\mathrm{Cd}, \mathrm{Pb}, \mathrm{Co}$ and $\mathrm{Mn}$ concentrations among regions (figure 2). The different letter showed that the groups were different. There was no difference detected among regions for Co. Higher $\mathrm{Cd}$ in Hainan Province and lower $\mathrm{Pb}$ and $\mathrm{Mn}$ in Inner Mongolia Province were found than other regions. It has been reported that heavy metals $(\mathrm{Cd}, \mathrm{Pb}$, $\mathrm{Hg}$, etc.) have accumulated in fish; health risks of metal pollution in humans through eating fish near the sea was higher than other region studied. The high metal accumulations $(\mathrm{Pb}$ and $\mathrm{Cd})$ were recorded in the fish species (e.g. Channa punctatus) [10]. Ingestion of fish was considered as the main pathway of human exposure to $\mathrm{Hg}$, $\mathrm{Cd}$ and $\mathrm{Pb}$, particularly for coast side populations, where fish was the main source of protein [11].

\subsection{Correlations between Metal Concentrations and Gender, Age}

Heavy metal content in hair was tested with the Mann-Whitney test by different gender and age (figure 3). Higher hair $\mathrm{Cd}(p<0.013)$ and lower hair $\mathrm{Co}(p<0.001)$ were found in female than male. No significant difference in hair $\mathrm{Pb}$ between female and male were observed. The result was consistent with a previous study which reported $\mathrm{Cd}$ concentration was higher in females than males, while that $\mathrm{Pb}$ was higher in men [3]. However, it has been reported that $\mathrm{Cd}$ contents in male were higher than in female, whereas that was not statistically different [7]. 

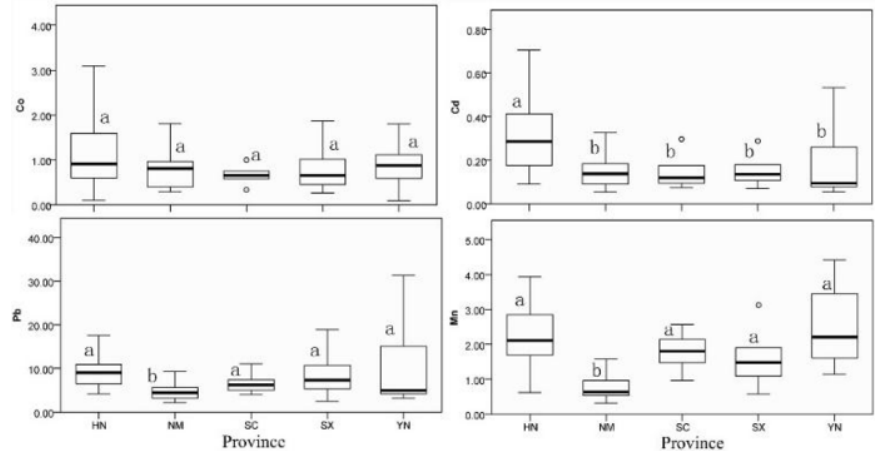

Figure 2. Difference in heavy metals concentrations $(\mu \mathrm{g} / \mathrm{g})$ among regions (Different letters indicate significant differences)
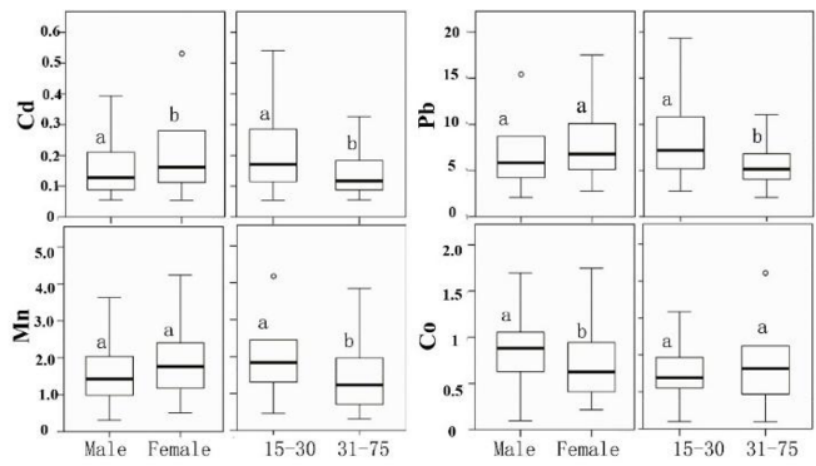

Figure 3. Heavy metal contents in hair with different gender and age.

The age for all volunteers was different from 15 to 75 years, two groups were classified into according to their age $(=<30$ and $>30)$. Heavy metals in two groups were tested by the Student's test. A significant difference of $\mathrm{Pb}$ concentrations in hair $(p<0.05)$ between these two groups were found. Higher $\mathrm{Pb}$ concentration in hair in the younger group $(=<30)$ was found than that the elder group $(>30)$. However, no significant differences in $\mathrm{Co}, \mathrm{Cd}$, and $\mathrm{Mn}$ in hair were found among these two groups. Many characteristics (age, sex, diary habit, geographical location, etc.) might affect heavy metals content in human hair. The negative relationship was found for age and $\mathrm{Cd}$ and $\mathrm{Pb}$ contents in a previous study in Hainan Province [12].

\subsection{Correlations between Metal Concentrations and Lifestyles, Dietary Habit}

$\mathrm{Cd}, \mathrm{Pb}, \mathrm{Co}$ and $\mathrm{Mn}$ in hair with different staple food were shown in figure $4 . \mathrm{Cd}, \mathrm{Pb}$, $\mathrm{Co}$ and $\mathrm{Mn}$ concentrations in hair were tested for significance in three groups by the Kruskal-Wallis $\mathrm{H}$ test. $\mathrm{Pb}$ concentration in hair was statistically different in three groups $(p<0.01)$, the hair $\mathrm{Pb}$ and $\mathrm{Cd}$ concentrations in rice consumers were higher than those in wheat consumers or both rice and wheat consumers, but $\mathrm{Cd}$ and $\mathrm{Co}$ were not different $(p>0.3)$. Dietary Cd intakes were significantly associated with $\mathrm{Cd}$ contents in fecal and blood [9]. The ratios of $\mathrm{Cd}$ and $\mathrm{Pb}$ contents in scalp hair and wheat grain sampled neighboring a $\mathrm{Pb}$ smelter site in China were reported as 2.03-4.92 and 40.4-203, respectively [13]. The result indicated that $\mathrm{Pb}$ accumulation was higher than 
$\mathrm{Cd}$ accumulation in human hair, which was consistent with that our result. Future investigations on the main path of $\mathrm{Cd}, \mathrm{Pb}$ and $\mathrm{Co}$ entering into human body associated with staple food are needed.

$\mathrm{Cd}, \mathrm{Pb}, \mathrm{Co}$ and $\mathrm{Mn}$ in hair in two groups of smokers (44.6\%) and non-smokers (55.4\%) were shown in figure 4 . The Mann-Whitney test was applied to compare Cd, $\mathrm{Pb}, \mathrm{Co}$ and $\mathrm{Mn}$ exposures between smokers and non-smokers. Heavy metal concentrations did not differ statistically between smokers and non-smokers $(p=0.62$, $0.57,0.59$ and 0.13 for $\mathrm{Cd}, \mathrm{Pb}, \mathrm{Co}$ and $\mathrm{Mn}$, respectively). However, significantly higher concentrations of $\mathrm{Cd}$ in blood $(p<0.0001)$ and urine $(p<0.0001)$ were observed in smokers than non-smokers in a previous study [3]. Alcohol drinking was certainly related with hair $\mathrm{Cd}$ and $\mathrm{Na}$ concentrations, while smoking habit was not positively corelated with other elements [12]. This was possibly because the accumulated $\mathrm{Cd}, \mathrm{Pb}$ and $\mathrm{Co}$ in tobacco would take into human body by smoking, but that was not considered to be metabolized by human hair. Dietary Cd ingestions were statistically associated with $\mathrm{Cd}$ concentrations in fecal and blood [9].

Hair $\mathrm{Cd}, \mathrm{Pb}, \mathrm{Co}$ and $\mathrm{Mn}$ between different fish consumption frequency were tested for significance by the Mann-Whitney $U$ test. Human with fish consumption frequently had higher $\mathrm{Cd}$ and $\mathrm{Pb}$ concentrations than infrequently $(p<0.05)$, but Co did not differ statistically $(p>0.1) \mathrm{Hg}, \mathrm{Cd}$ and $\mathrm{Pb}$ concentrations were measured in muscle in fish commonly consumed in Italy. $\mathrm{Hg}$ concentrations in 5 species was the highest, followed by $\mathrm{Pb}$ and $\mathrm{Cd}$, that presented comparable levels [14]. A significant correlation was found between fish consumption and $\mathrm{Hg}$ concentrations in hair and blood [7]. However, that the consumption of fish may pose a health risk of $\mathrm{Cd}$ and $\mathrm{Pb}$ was rarely reported.

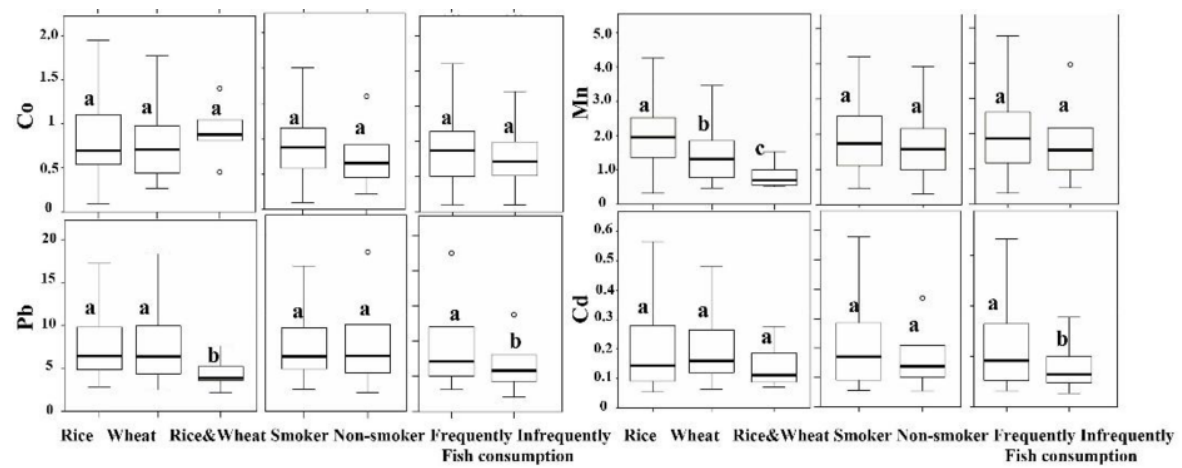

Figure 4. Heavy metal concentrations in hair with different food habit and lifestyle.

\section{Conclusion}

(1) Heavy metal concentrations in 150 human hairs samples collected from five provinces in China were $1.62 \mu \mathrm{g} / \mathrm{g}(\mathrm{Mn}), 0.99 \mu \mathrm{g} / \mathrm{g}(\mathrm{Co}), 0.22 \mu \mathrm{g} / \mathrm{g}(\mathrm{Cd})$ and $8.49 \mu \mathrm{g} / \mathrm{g}$ $(\mathrm{Pb})$, which were within the normal range, but were lower compared with those reported in mine contaminated areas. The general populations have common exposure sources (dairy diet, etc.) to $\mathrm{Cd}$ and $\mathrm{Pb}$.

(2) The gender, age, diet and lifestyle habits of the volunteers were investigated to analyze their effects on hair element concentrations. Cd concentration was higher in females than males, $\mathrm{Pb}$ concentration was higher in the younger group (age $=<30$ ) than 
the elder group (age $>30$ ). The difference of $\mathrm{Cd}$ and Co concentrations was not found among rice consumers and/or wheat consumers. $\mathrm{Pb}$ concentration in rice consumers were higher than those in rice and/or wheat consumers. Fish consumption were a factor affecting hair $\mathrm{Cd}$ and $\mathrm{Pb}$ levels, while smoking was not one main pathway of hair $\mathrm{Cd}$ and $\mathrm{Pb}$ exposure.

\section{References}

[1] Örün E, Yalcin SS, Aykut O. Lead, mercury, and cadmium levels in breast milk and infant hair in the late period of lactation in Ankara, Turkey. International Journal of Environmental Health Research. 2021 Jun;(2):1-12.

[2] Bechtold P, Gatti MG, Quattrini G, Ferrari A, Barbieri G, Iacuzio L, Carrozzi G, Righi E. Trace elements in toenails in a population living near a modern municipal solid waste incinerator in Modena (Italy). Chemosphere. 2021 Jan; 263:128292.

[3] Saravanabhavan G, Werry K, Walker M, Haines D, Malowany M, Khoury C. Human biomonitoring reference values for metals and trace elements in blood and urine derived from the Canadian Health Measures Survey 2007-2013. International Journal of Hygiene and Environmental Health. 2017 Mar; 220(2, Part A):189-200.

[4] Skalny AV, Skalnaya MG, Grabeklis AR, Zhegalova IV, Serebryansky EP, Demidov VA, Salnikova EV, Uzhentseva MS, Lobanova YN, Skalny AA, Tinkov AA. Interactive effects of age and gender on levels of toxic and potentially toxic metals in children hair in different urban environments. International Journal of Environmental Analytical Chemistry. 2018 June;98(6):520-535.

[5] Tian ML, Zhong XM, Xia DS, Fu FY, Lu SF, Li L, Song B. Characteristics of heavy metal contents in human hairs of mine contaminated areas in Nandan County. Environmental Science. 2016 Dec;37(12):4867-4876.

[6] Zhou T, Wang Z, Christie P, Wu L. Cadmium and lead pollution characteristics of soils, vegetables and human hair around an open-cast lead-zinc mine. Bulletin of Environmental Contamination and Toxicology. 2021 Feb. doi:10.1007/s00128-021-03134-6.

[7] Alcala-Orozco M, Caballero-Gallardo K, Olivero-Verbel J. Biomonitoring of mercury, cadmium and selenium in fish and the population of puerto nariño, at the southern corner of the Colombian Amazon. Archives of Environmental Contamination and Toxicology. 2020 Oct;79(3):354-370.

[8] Selahvarzi S. Ardakani SS. Analysis and health risk assessment of toxic $(\mathrm{Cd}$ and $\mathrm{Pb})$ and essential $(\mathrm{Cu}$ and $\mathrm{Zn}$ ) elements through consumption of potato (Solanum tuberosum) cultivated in Iran. International Journal of Environmental Analytical Chemistry. 2020 Aug; Doi: 10.1080/03067319.2020.1807974.

[9] Wang Y, Ou YL, Liu YQ, Xie Q, Liu QF, Wu Q. Fan TQ, Yan LL, Wang JY. Correlations of trace element levels in the diet, blood, urine, and feces in the Chinese male. Biological Trace Element Research. 2012 Feb;145(2):127-135.

[10] Kalita S, Kumar S, Sarma HP, Devi A. Total organic carbon, heavy metal content and metal bioaccumulation in a freshwater wetland of Indo-Burmese province, India. International Journal of Environmental Analytical Chemistry. 2021 May; (9):1-15.

[11] Fernandez-Maestre R, Johnson-Restrepo B, Olivero-Verbel J. Heavy metals in sediments and fish in the Caribbean Coast of Colombia: Assessing the environmental risk. International Journal of Environmental Research. 2018 Jun;12(3):289-301.

[12] Hao Z, Li Y, Liu Y, Li H, Wang W, Yu J. Hair elements and healthy aging: a cross-sectional study in Hainan Island, China. Environmental Geochemistry and Health. 2016 Jun;38(3):723-735.

[13] Li L, Zhang Y, Ippolito JA, Xing W, Qiu K, Yang H. Lead smelting effects heavy metal concentrations in soils, wheat, and potentially humans. Environmental Pollution. 2020 Feb; 257:113641.

[14] Ariyaee M, Azadi NA, Majnoni F, Mansouri B. Comparison of metal concentrations in the organs of two fish species from the zabol chahnimeh reservoirs, Iran. Bulletin of Environmental Contamination and Toxicology. 2015 Jun; 94(6): 715-721. 